\title{
前立腺癌の早期診断における検診の意義
}

\begin{tabular}{llllllll}
\multicolumn{8}{c}{ 杏林大学医学部泌尿器科学教室 (主任 : 東原英二教授) } \\
加藤 & 司顯 & 多武保光宏 & 吉松 & 正 & 太田 & 雅也 \\
金城 & 真実 & 野田 & 治久 & 渡辺 & 和吉 & 宮田 & 晃臣 \\
村田 & 明弘 & 三浦 & 一郎 & 米田 & 龍生 & 吉井 & 将人 \\
桶川 & 隆嗣 & 小島 & 美保 & 佐山 & 孝 & 奴田原紀久雄 \\
東原 & 英二 & & & & & &
\end{tabular}

\section{THE SIGNIFICANCE OF EARLY DETECTION FOR PROSTATE CANCER IN MASS SCREENING}

\author{
Moriaki Kato, Mitsuhiro Tammbo, Tadashi Yoshimatsu, Msaya Ohta, Manami Kinjyo, \\ Haruhisa Noda, Kazuyosi Watanabe, Akiomi Miyata, Akihiro Murata, Ichiro Miura, \\ Tatsuo Yoneda, Masahito Yoshii, Takatsugu Okegawa, Miho Kojima, Takasi Sayama, \\ Kikuo Nutahara and Eiji Higashihara \\ Department of Urology, Kyorin University School of medicine. \\ (Chief: Prof, Eiji Higashihara)
}

(Purpose) In Mitaka city, mass screening for prostate cancer was conducted for 3 years from 1995 to 1997. Clinical stages were compared between patients found by screening and those diagnosed at our clinic during the same time. The significance of serum-free prostate specific antigen (PSA) in mass screening for prostate cancer was examined.

(Material and Methods) A prospective clinical trial was conducted on men aged 50 years or older. The primary examination consisted of taking the international prostate symptom score. quality of life score, PSA (Tandem-R) and digital rectal examination (DRE). If PSA was greater than 4.0 $\mathrm{ng}$./ $\mathrm{ml}$ and/or if DRE suggested cancer, transrectal ultrasound-guided sextant prostate biopsies were indicated.

(Results) Of the men screened, 23.2\% (320/1375) had serum PSA greater than $4.0 \mathrm{ng} . / \mathrm{ml}$. and /or suspicious findings on DRE. Biopsy was performed in 199 of $320(62.1 \%)$. Cancer was detected in $21(1.5 \%, 21 / 1375)$. Prostate cancer was found in one case among 154 males $(0.65 \%, 1 / 154)$ who were screened twice or more.

The cancer stage found by screening was significantly earlier than that diagnosed at the outpatient clinic (Wilcoxon's rank-sum test : $\mathrm{p}=0.0047$ ).

Receiver operating characteristics analysis showed that the optimal free PSA-to-PSA ratio was $12 \%$. Positive predictive value increased from $18 \%$ to $50 \%$ when free PSA-to-PSA ratio was combined with PSA.

(Conclusion) 1. Cancer detection rate was 1.5\% in the mass screening in Mitaka City. 2. Cancer stage found by screeing was significantly earlier than that diagnosed at the outpatient clinic. 3. Free PSA determination might eliminate unnecessary biopsies in men with PSA above $4.0 \mathrm{ng} . / \mathrm{ml}$ with minimal loss of cancer detection.

Key words : Prostate cancer, Mass screening, PSA 
要旨：(目的） 1995 年より 3 年間, 三鷹市で前立腺癌検診を施行し, 検診の結果を外来受診で前立腺癌と 診断された症例と比較した。 また前立腺癌検診における free-PSAの前立腺癌スクリーニング上の有用 性についても検討した.

（対象および方法）50歳以上の男性を対象とし, 一次検診として, International prostate symptom score・Quality of life score の記入, Tandem-R による Prostate specific antigen（PSA）の測定，および 直腸指診を行った. PSA が $4.1 \mathrm{ng} / \mathrm{ml}$ 以上もしくは直腸指診で異常を認めた場合を二次検診該当者とし た. 二次検診として free PSA (Tandem-R) の測定, 経直腸超音波ガイド下に 6 力所前立腺針生検を施行 した.

（結果） 1,375 名の受診者の内 320 名 $(320 / 1,375 ; 23.2 \%)$ が二次検診の対象となった. その内 199 名 $(199 / 320 ; 62.1 \%)$ に前立腺生検を施行し 21 名に前立腺癌を認めた $(21 / 1,375 ; 1.5 \%)$. 同時期に外来受診 で前立腺癌と診断された症例 $(\mathrm{n}=141)$ との臨床病期の比較では, 有意差をもって検診受診者が早期に 診断されていた $(\mathrm{p}=0.0047)$. ROC 曲線から求めた free-PSA ratio の境界值 $12 \%$ を PSA $4.1 \mathrm{ng} / \mathrm{ml}$ 以上 と併用すると Positive predictive value は $18 \%$ から $50 \%$ に上昇した.

(結語）前立腺癌患者は検診によって外来患者よりも早期の病期で診断され, また, PSA と free-PSA とを併用することで, 検診効率を上げられることが示唆された.

キーワード：前立腺癌, 検診, PSA

\section{緒言}

前立腺疾患における検診は, 本邦では 1975 年に京都 府立医大が開始し，1981 年には群馬県前立腺検診グ ループ（群馬大）が加わるなど，1997 年の段階で前立 腺集団検診を行っている施設は 43 施設に及んでい る $^{122)}$.

東京都三鷹市は人口 161,442 人，このうち 50 歳以上 男性は 53,980 人の都市である. 1994 年までは前立腺癌 検診が行われていなかった三鷹市において，1995 年よ り 1997 年の 3 年間に前立腺癌検診（1997 年は前立腺 肥大症も含めた前立腺検診を施行した。）を施行したの でその結果を報告する.

前立腺癌検診の結果は, 同時期に外来で前立腺癌と 診断された症例, および PSA 導入以前に前立腺癌と診 断された当院の過去の症例（1976〜1986 年）と比較検 討し，また前立腺癌検診における free-PSA の前立腺 癌マーカーとしての有用性についても検討したので報 告する.

\section{対象および方法}

東京都三鷹市の 50 歳以上の男性を対象とし, 市内の コミュニティーセンター（図書館などを併設した地域 の集会所）でのポスター揭示，および三鷹市報に告示 し希望者を募った。希望者全て一次検診対象者とし, 市内 8 カ所のコミュニティーセンターを検診会場とし て検診を行った. 内容は以下に示す.

(1) International prostate symptom score (IPSS) • Quality of life（QOL） スコアーの記入.
(2) Tandem-Rによる Prostate specific antigen（前 立腺特異抗原, PSA）の測定.

(3) 直腸指診（1997 年度検診では希望者のみに施行 した.)

PSA：4.1ng/dl 以上もしくは直腸指診で異常を認め た場合を二次検診該当者とし郵送にて結果を通知し た. 二次検診として杏林大学医学部付属病院を受診し たものには, (1) free PSA（Tandem-R）の測定, (2) B $\& \mathrm{~K}$ 社製経直腸超音波ガイド下に 6 力所前立腺針生 検を施行した.

杏林大学を二次検診で受診しなかったものには．手 紙あるいは電話で追跡調査を行った。

\section{結 果}

\section{1. 検診受診者}

三鷹市前立腺癌検診結果を表 1 に示す. 1,375 名の受 診者の内 320 名が二次検診の対象となった. その内 199 名に前立腺生検が施行され，21 名に前立腺癌を認 めた $(21 / 1,375 ; 1.5 \%)$ 。このうち重複受診者は 154 名であり，二次検診該当者が 37 名，1名に前立腺癌を 認めた $(1 / 154 ; 0.65 \%)$ 一次検診受診者の平均年齢は $66.6 \pm 7.4$ 歳であった。

\section{2. 年齢階級別結果}

年齢別受診者数と癌の割合を表 2 に示す．受診者数 は 65〜69 歳が最も多く, 癌患者の平均年齢は $74.7 \pm$ 9.5 歳であった．高齢になるほど癌発見率は高くなり， 85 歳を越える受診者は 10 名いたが，その $20 \%$ に前立 腺癌が見出された。 
表 1 三鷹市前立腺癌検診結果

\begin{tabular}{|c|c|c|c|c|c|c|c|c|c|c|}
\hline & \multirow{2}{*}{$\begin{array}{c}\text { 一次検診 } \\
\text { 受診者 }\end{array}$} & \multicolumn{3}{|c|}{ 一次検診結果 } & \multirow{2}{*}{$\begin{array}{l}\text { 二次検診 } \\
\text { 該当者数 }\end{array}$} & \multirow{2}{*}{$\begin{array}{l}\text { 二次検診 } \\
\text { 受診者数 }\end{array}$} & \multicolumn{2}{|c|}{ 二次検診結果 } & \multicolumn{2}{|c|}{ 癌発見率 (\%) } \\
\hline & & $\mathrm{PSA}>4.0$ & 直腸指診陽性 & 両者陽性群 & & & 癌 & 正常 & $\begin{array}{l}\text { 対一次検診 } \\
\text { 受診者数 }\end{array}$ & $\begin{array}{c}\text { 対二次検診 } \\
\text { 受診者数 }\end{array}$ \\
\hline 1995 年受診者 & 701 & 79 & 135 & 27 & 187 & 116 & 13 & 103 & 1.8 & 11.2 \\
\hline 1996 年受診者 & 406 & 30 & 54 & 11 & 73 & 49 & 5 & 44 & 1.2 & 10.2 \\
\hline 1997 年受診者 & 268 & 27 & 42 & 9 & 60 & 34 & 3 & 31 & 1.1 & 8.8 \\
\hline 総数 & 1,375 & 136 & 231 & 47 & 320 & 199 & 21 & 178 & 1.5 & 10.6 \\
\hline 重複受診者 & 154 & 18 & 27 & 7 & 37 & 18 & 1 & 17 & 0.6 & 5.5 \\
\hline
\end{tabular}

表 2 年歯階級別受診者数と癌の割合

\begin{tabular}{|c|c|c|c|c|c|c|c|c|c|c|c|c|c|c|c|c|c|}
\hline \multirow[t]{2}{*}{ 年齢 } & \multicolumn{4}{|c|}{ 一次検診受診者数 } & \multicolumn{4}{|c|}{ 二次検診該当者数 } & \multicolumn{4}{|c|}{ 二次検診受診者数 } & \multicolumn{4}{|c|}{ 前立腺癌確定者数 } & \multirow{2}{*}{$\begin{array}{l}\text { 癌発見率 } \\
\text { (対一次検診 } \\
\text { 受診者数) }\end{array}$} \\
\hline & $\begin{array}{c}1995 \\
\text { 年 }\end{array}$ & $\begin{array}{c}1996 \\
\text { 年 }\end{array}$ & $\begin{array}{c}1997 \\
\text { 年 }\end{array}$ & 計 & $\begin{array}{c}1995 \\
\text { 年 }\end{array}$ & $\begin{array}{c}1996 \\
\text { 年 }\end{array}$ & $\begin{array}{c}1997 \\
\text { 年 }\end{array}$ & 計 & $\begin{array}{c}1995 \\
\text { 年 }\end{array}$ & $\begin{array}{c}1996 \\
\text { 年 }\end{array}$ & $\begin{array}{c}1997 \\
\text { 年 }\end{array}$ & 計 & $\begin{array}{c}1995 \\
\text { 年 }\end{array}$ & $\begin{array}{c}1996 \\
\text { 年 }\end{array}$ & $\begin{array}{c}1997 \\
\text { 年 }\end{array}$ & 計 & \\
\hline $50-54$ & 68 & 38 & 16 & 122 & 3 & 3 & 4 & 10 & 1 & 2 & 3 & 6 & 0 & 1 & 1 & 2 & 1.6 \\
\hline $55-59$ & 100 & 41 & 23 & 164 & 18 & 2 & 4 & 24 & 10 & 1 & 3 & 14 & 0 & 0 & 1 & 1 & 0.6 \\
\hline $60-64$ & 150 & 99 & 58 & 307 & 32 & 17 & 8 & 57 & 16 & 13 & 2 & 31 & 0 & 2 & 0 & 2 & 0.7 \\
\hline $65-69$ & 180 & 105 & 82 & 367 & 53 & 24 & 22 & 99 & 37 & 15 & 13 & 65 & 3 & 1 & 0 & 4 & 1.1 \\
\hline $70-74$ & 111 & 80 & 58 & 249 & 38 & 15 & 18 & 71 & 23 & 12 & 11 & 46 & 2 & 1 & 0 & 3 & 1.2 \\
\hline $75-79$ & 60 & 29 & 20 & 109 & 28 & 8 & 2 & 38 & 19 & 4 & 2 & 25 & 3 & 0 & 1 & 4 & 3.7 \\
\hline $80-84$ & 25 & 12 & 10 & 47 & 12 & 4 & 1 & 17 & 8 & 1 & 0 & 9 & 3 & 0 & 0 & 3 & 6.4 \\
\hline $85-$ & 7 & 2 & 1 & 10 & 3 & 0 & 1 & 4 & 2 & 1 & 0 & 3 & 2 & 0 & 0 & 2 & 20 \\
\hline 総数 & 701 & 406 & 268 & 1,375 & 187 & 73 & 60 & 320 & 116 & 49 & 34 & 199 & 13 & 5 & 3 & 21 & 1.5 \\
\hline
\end{tabular}

表 3 PSA 分布と癌の割合

\begin{tabular}{c|c|c|c}
\hline PSA 分布 & 総数 $(\%)$ & 癌患者数 & $\begin{array}{c}\text { 癌の割合 } \% \\
\text { (癌 / 総数) }\end{array}$ \\
\hline $4.0 \mathrm{ng} / \mathrm{ml}$ 以下 & $1,239(90.1)$ & 2 & 0.2 \\
$4.1-9.9 \mathrm{ng} / \mathrm{ml}$ & $105(7.6)$ & 7 & 6.7 \\
$10.0 \mathrm{ng} / \mathrm{ml}$ 以上 & $31(2.3)$ & 12 & 38.7 \\
\hline
\end{tabular}

\section{PSAの分布と癌の割合}

表 3 には PSA の分布と癌の割合を示す. PSA が 4.0 $\mathrm{ng} / \mathrm{ml}$ 以下の症例が大部分であったが，2名 $(0.2 \%)$ の 癌患者を認めた。またPSA $10.0 \mathrm{ng} / \mathrm{ml}$ 以上では約 40 \%に癌が見出された。

\section{4. 自覚症状}

表 4 に癌患者・非癌患者の IPSS・QOL スコアーの 比較を示す. IPSS は癌患者と非癌患者との間に有意差 を認めなかった.QOL スコアーでは, 癌患者と一次検 診受診者の非癌患者との間において有意差を認めた が, 癌患者の平均年齢は 74.7 歳であり, 1 次検診受診者 の平均年齢は 66.6 歳と有意に低いことに起因してい ると考える. 2 次検診受診者の非癌患者と癌患者の間
に㧍いては，IPSS・QOL スコアーの有意差は認めな かった.この結果より, 前立腺肥大症も含めた前立腺 検診では有用であろう IPSS・QOL スコアーの記入 は，癌発見を目的とした検診では有効な手段ではない と考えられた。

\section{5. 臨床病期}

臨床病期は stage B が 13 名, stage C が 5 名, stage D が 3 名であり，1997 年度検診では stage C, D 症例 は認めなかった。

この検診結果を外来受診で前立腺癌を認めた症例と 比較した。対象は 1995 年 4 月から 1998 年 1 月までに 当院泌尿器科外来を受診した 50 歳以上の男性で, 検診 と同様の基準である PSA $4.1 \mathrm{ng} / \mathrm{ml}$ 以上又は直腸指診 で異常を認め前立腺生検を施行した 634 名のうち，前 立腺癌を認めた 141 名 $(22.2 \%)$ である.

検診に参加する方が，病院の外来受診より容易であ り，また症状が強くなっていることが推測され，この 二群間には当然自覚症状の差があると考える. しかし 1995 年から 1996 年の外来ではIPSSを調べていな かったため, 自覚症状の比較はできなかった. 
表 4 癌患者·非癌患者の IPSS - QOL スコアーの比較

\begin{tabular}{|c|c|c|c|c|c|}
\hline & 年齢 (歳) & & IPSS & & QOL スコアー \\
\hline $\begin{array}{l}\text { 癌患者 } \\
\qquad(\mathrm{n}=21)\end{array}$ & $74.7 \pm 9.5 \square *$ & & $10.8 \pm 7.5\rceil$ & & $3.7 \pm 1.4 \square \#$ \\
\hline $\begin{array}{c}\text { 一次検診 受診非癌患者 } \\
(\mathrm{n}=1,354)\end{array}$ & $66.6 \pm 7.4=$ * & * & $8.3 \pm 6.7=\star$ & $\star$ & $2.8 \pm 1.4=\star$ \\
\hline $\begin{array}{c}\text { 二次検診 受診非癌患者 } \\
(\mathrm{n}=178)\end{array}$ & $68.9 \pm 7.0 \square$ & & $9.3 \pm 7.1$ & & $3.7 \pm 1.3$ \\
\hline
\end{tabular}

表 5 外来・検診受診の癌患者の比較

\begin{tabular}{|c|c|c|c|}
\hline & & $\begin{array}{c}\text { 外来受診者 } \\
(\mathrm{n}=141)\end{array}$ & $\begin{array}{c}\text { 検診受診者 } \\
(\mathrm{n}=21)\end{array}$ \\
\hline \multicolumn{4}{|l|}{ 年齢 } \\
\hline & $50-59$ & $6(4 \%)$ & $3(14 \%)$ \\
\hline & $60-69$ & $39(7 \%)$ & $6(29 \%)$ \\
\hline & $70-79$ & $49(35 \%)$ & $7(43 \%)$ \\
\hline & $80-$ & $47(33 \%)$ & $5(24 \%)$ \\
\hline & & 平均 $75.2 \pm 9.2$ & 平均 $74.7 \pm 9.5$ \\
\hline \multicolumn{4}{|l|}{ PSA } \\
\hline & $0-4.0$ & $6(4 \%)$ & $2(10 \%)$ \\
\hline & $4.1-9.9$ & $27(19 \%)$ & $7(33 \%)$ \\
\hline & $10-$ & $108(77 \%)$ & $12(57 \%)$ \\
\hline & & 平均 $38.4 \pm 49.2$ & 平均 $29.3 \pm 30.0$ \\
\hline \multicolumn{4}{|l|}{ 臨床病期 } \\
\hline & B & $47(33 \%)$ & $13(62 \%)$ \\
\hline & $\mathrm{C}$ & $32(23 \%)$ & $5(24 \%)$ \\
\hline & $\mathrm{D}$ & $62(44 \%)$ & $3(14 \%)$ \\
\hline
\end{tabular}

表 5 に外来および検診受診者で癌と診断された症例 の年齢・PSA 分布 ・ 臨床病期の比較を示す. 当院一般 外来で癌と診断された症例の平均年齢と前立腺癌検診 で癌と診断された症例の平均年齢との両群間に統計学 的有意差は認めず，また年齢分布にも有意差は認めな かった.

PSAの比較でも, 外来受診者と検診受診者の平均 值・分布ともに統計学的有意差は認めなかった.

臨床病期の比較では検診の方が, Wilcoxon's ranksum test で有意 $(\mathrm{p}=0.0047)$ に早期に診断されていた.

PSA の分布が同様でも, 検診の方が早期に発見され ていた理由としては, 検診でみつかった癌患者の症例 数が少なかったためと考える.

\section{考察}

三鷹市前立腺癌検診の 3 年間での癌発見率は $1.5 \%$
であった. 表 6 に癌発見率と PSA の分布比較につい て, 1997 年の日本の全国集計 ${ }^{2)}$, 米国・ Labrie ${ }^{5)}$, Catalona ${ }^{6}$ の報告との比較を示す.

癌発見率は全国集計よりも三鷹市の方が高かった $(\mathrm{p}=0.0065)$.二次検診受診率は全国集計は $71.3 \%$ ，三 鷹市検診は $62.1 \%$ でむしろ全国平均の方が高かった. 年次毎検診を行っている地域では発見率が下がるこ と, 三鷹市の二次検診のほとんどは超音波ガイド下に 6 力所生検を施行していること, 使用した PSA のキッ トの差，検診システムの差などが原因で，全国集計と の差になったと考える.

しかし三鷹市の癌発見率は, 米国と比較すると有意 に低い結果であった。人種の差, 食事など環境差の影 響により前立腺癌䍜患率は米国の方が高いことが知ら れているが，前立腺癌に対する一般市民と医療従事者 の認識が低いことも本邦での癌発見率が低い原因に なっているのかもしれない.

PSA は, $4.0 \mathrm{ng} / \mathrm{ml}$ 以下と $4.1 \sim 9.9 \mathrm{ng} / \mathrm{ml}$ の分布にお いて Catalonaの報告 ${ }^{6}$ と比し有意差を認めたが, Labrie の報告5) と比した場合, 差は認めなかった. 同じ 測定法を用いたPSAの分布については三鷹市と米国 との間に大きな差を認めなかったが，癌発見に差があ る原因は不明である.

検診結果を PSA 導入以前に前立腺癌と診断された 当院の過去の症例9)（1976～1986 年）と比較検討を 行った。

図 1 に検診・および当院に於ける年代別の前立腺癌 患者の臨床病期の比較を示す. PSA 導入前の 1976〜 1986 年の当院における前立腺癌のまとめ ${ }^{9)}$, PSA 導 入後の 1995 1998 年の外来受診で癌を認めた症例と 検診とを比較した。病期 A は検診との比較上はずし, 各々 100\%になるように比較した.

1976１986 年・1995１998 年・検診における各々 の臨床病期別頻度は, Stage B $11 \% \cdot 31 \% \cdot 62 \%$, Stage C $12 \% \cdot 29 \% \cdot 24 \%$, Stage D $77 \% \cdot 40 \% \cdot 14$ 
表 6 癌発見率とPSA の分布比較

\begin{tabular}{l|r|c|c|c}
\hline & \multicolumn{1}{|c|}{ 癌発見率 } & \multicolumn{3}{|c}{ PSA の值 } \\
\cline { 2 - 5 } & 癌患者/総数(\%) & $4.0 \mathrm{ng} / \mathrm{ml}$ 以下 & $4.1-9.9 \mathrm{ng} / \mathrm{ml}$ & $10 \mathrm{ng} / \mathrm{ml}$ 以上 \\
\hline 1) 自験例 & $21 / 1,375(1.5 \%)$ & $1,239(90.1 \%)$ & $105(7.6 \%)$ & $31(2.3 \%)$ \\
2) 全国集計(日本) ${ }^{2)}$ & $161 / 20,232(0.8 \%)$ & $/$ & $/$ & $/$ \\
3) Catalona et al.6) & $264 / 6,630(3.9 \%)$ & $5,647(85.2 \%)$ & $809(12.2 \%)$ & $174(2.6 \%)$ \\
4) Labrie et al.5) & $57 / 1,002(5.7 \%)$ & $878(87.6 \%)$ & $89(8.9 \%)$ & $35(3.5 \%)$ \\
\hline
\end{tabular}

図 1 検診と PSA 導入前後で診断された前立腺癌患 者の臨床病期比較

1976 - 1986 V.S. 1995 - $1998 ; \mathrm{p}<0.0001$

1995-1998 V.S. 検診 ; $\mathrm{p}<0.0001$

1976-1986 V.S. 検診 ; $\mathrm{p}<0.0001$

(\%)

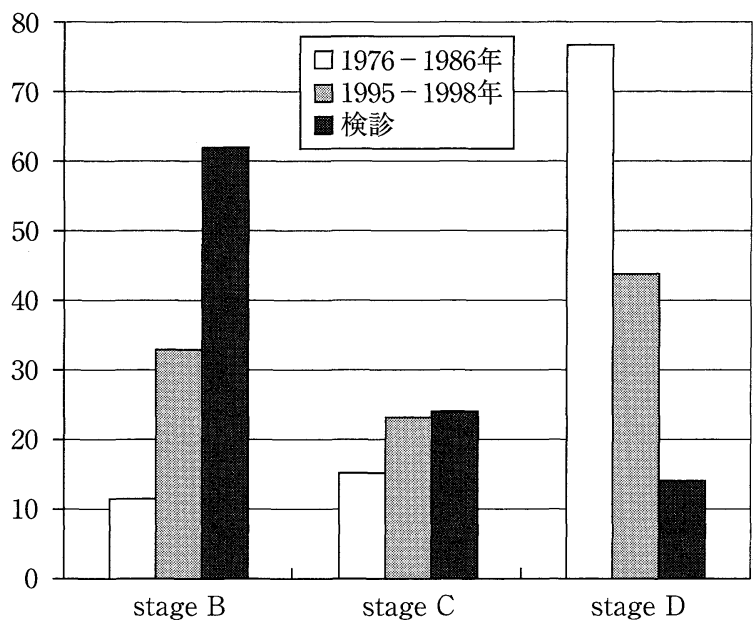

\%であった，過去よりも現在の外来受診者が，またそ のどちらよりも検診の方が, Wilcoxon's rank-sum test で有意差をもって早期に診断されていた.

PSA を主体にした検診で，このように前立腺癌はよ り早期に診断されるようになってきているが, PSA の欠点ではその疑陽性の高さにある. free-PSA ratio が前立腺癌のスクリーニングに有用であることは近年 報告されている ${ }^{15116)}$. しかしながら, free-PSA ratio の境界值をどこにとるかは問題の残るところである. 今回我々はPSA $4.1 \mathrm{ng} / \mathrm{ml}$ 以上での free-PSA ratio の ROC 曲線で Area Ander the Curve を比較したとこ ろ，12\%での面積が最大であったため，12\% および， Oesterling $^{15)}$ や Catalona ${ }^{16)}$ は感受性を 90\%に保つため には 23〜31\%を境界值として提唱しているため, 23
\%と $31 \%$ にても Positive predictive value (PPV) を求 めた (表 7).

PSA 4.1ng/ml 以上のみで生検の適応を決めた場合, 108 人に生検を施行し 19 人に癌を認めたため, $18 \%$ の PPV となる.このことは 89 人の健常者にも生検を施 行するということになる.

また, PSA 4.0ng/ml 以下では, 2 例の癌 (臨床病期, Stage B）が直腸指診で検出されていた。しかし PSA $4.0 \mathrm{ng} / \mathrm{ml}$ 以下における直腸指診は, PPV が $0.7 \%$ と極 めて低值であり，集検という立場から考えると効率の 悪い検査であった.一方, PSA $4.1 \mathrm{ng} / \mathrm{ml}$ 以上の場合に はPPVは $31 \%$ となり，直腸指診は有効な検査である と考える。

free-PSA ratio を併用することにより，境界值を 31 \%とした場合でも PPVは $19 \%$ であり，生検者を 108 人から 102 人へ減少でき, 境界值を $23 \%$ とした場合に は 1 人の癌患者の見落としがあるが, 生検者を 94 人に 減少することができる.この 1 人の癌患者の臨床病期 は Stage Bであった.

$\mathrm{ROC}$ 曲線からもとめた $12 \%$ を境界值とした場合 は，生検者を 32 人に減らすことが可能となるが， 3 人の癌患者の見落としが出ることとなる.この 3 人の 臨床病期は Stage B が 2 人, Stage C が 1 人であり, 検 診という癌患者を逃さないという観点からは freePSA ratio の境界值は 23 から $31 \%$ が妥当なものと考 える.

前立腺癌検診は早期診断に有用であり，PSA を基礎 とした癌検診で, free PSA ratio を併用することで, 少 ない癌患者の見過ごしで, 多くの不必要な生検を省略 できることが示唆された。

\section{結 語}

1. 三鷹市前立腺癌検診で $1.5 \%$ に前立腺癌を認め た.

2. 前立腺癌患者は検診によって外来患者よりも早 期の病期で診断された。 
表 7 Free PSA ratio の各境界值における PPV (Positive Predictive Value)

\begin{tabular}{|c|c|c|c|c|}
\hline 直腸指診 & $\begin{array}{c}\text { free PSA ratio } \\
(\%)\end{array}$ & $\mathrm{PSA}(\mathrm{ng} / \mathrm{ml})$ & $\begin{array}{l}\text { Positive } \\
\text { Predictive } \\
\text { Value (\%) }\end{array}$ & $\begin{array}{c}\text { 癌の割合 } \\
\text { (癌 / 生検数) }\end{array}$ \\
\hline $\begin{array}{l}- \\
- \\
- \\
- \\
- \\
- \\
- \\
- \\
-\end{array}$ & $\begin{array}{c}- \\
- \\
- \\
12 \text { 以下 } \\
23 \text { 以下 } \\
31 \text { 以下 }\end{array}$ & $\begin{array}{c}4.1 \\
4.1-9.9 \\
10.0 \text { 以上 } \\
4.0 \text { 以下 } \\
4.1 \text { 以上 } \\
4.0 \text { 以下 } \\
4.1 \text { 以上 } \\
4.0 \text { 以下 } \\
4.1 \text { 以上 }\end{array}$ & $\begin{array}{c}18 \\
9 \\
46 \\
3.5 \\
50 \\
2.2 \\
19 \\
1.7 \\
19\end{array}$ & $\begin{array}{c}19 / / 108 \\
7 / / 82 \\
12 / / 26 \\
1 / / 29 \\
16 / / 32 \\
2 / / 90 \\
18 / / 94 \\
2 / / 118 \\
19 / / 102\end{array}$ \\
\hline 癌疑いあり & $\begin{array}{c}- \\
- \\
- \\
12 \text { 以下 } \\
23 \text { 以下 } \\
31 \text { 以下 }\end{array}$ & $\begin{array}{c}- \\
4.0 \text { 以下 } \\
4.0 \text { 以上 } \\
4.0 \text { 以下 } \\
4.1 \text { 以上 } \\
4.0 \text { 以下 } \\
4.1 \text { 以上 } \\
4.0 \text { 以下 } \\
4.1 \text { 以上 }\end{array}$ & $\begin{array}{c}7.4 \\
0.7 \\
31 \\
3.3 \\
60 \\
1 \\
31 \\
0.8 \\
32\end{array}$ & $\begin{array}{c}14 / / 175 \\
2 / / 136 \\
12 / / 39 \\
1 / / 30 \\
11 / / 20 \\
2 / / 89 \\
11 / / 35 \\
2 / / 118 \\
12 / / 37\end{array}$ \\
\hline 癌疑いなし & $\begin{array}{c}- \\
12 \text { 以下 } \\
23 \text { 以下 } \\
31 \text { 以下 }\end{array}$ & $\begin{array}{l}4.0 \text { 以下 } \\
4.1 \text { 以上 } \\
4.0 \text { 以下 } \\
4.1 \text { 以上 } \\
4.0 \text { 以下 } \\
4.1 \text { 以上 } \\
4.0 \text { 以下 } \\
4.1 \text { 以上 }\end{array}$ & $\begin{array}{c}* \\
10 \\
* \\
17 \\
* \\
12 \\
* \\
11\end{array}$ & $\begin{array}{c}* \\
7 / / 69 \\
* \\
4 / / 23 \\
* \\
7 / / 58 \\
* \\
7 / / 64\end{array}$ \\
\hline
\end{tabular}

一：施行せず．計算せず.

*：計算せず.

3. PSA と free-PSA とを併用することで, 検診効率 を上げられることが示唆された。

追記：三鷹市前立腺癌検診施行にあたり，御指導を賜り ました故志田圭三先生に深甚なる謝意を捧げます。

\section{文献}

1）前立腺検診協義会編集部：前立腺集団検診, 前立 腺検診の手引き, 前立腺検診協議会・前立腺研究 財団編集・p71-103, 金原出版，東京，1993.

2）前立腺検診協義会：前立腺集団検診全国集計一 1997 年度版一, p27一 37 , 東京, 1998.

3) Higashihara, E., Nutahara, K., Kojima, M., Okegawa, T., Miura, I., Miyata, A., Kato, M., Sugisaki, H. and Tomaru, T. : Significance of serum free prostate specific antigen in the screening of prostate cancer. J. Urol., 156, 1964-1968, 1996.
4) Higashihara, E., Nutahara, K., Kojima, M., Okegawa, T., Miura, I., Miyata, A., Kato, M., Sugisaki, H. and Tomaru, T. : Significance of serum free prostate specific antigen and gammaseminoprotein in the screening of prostate cancer. Prostate (Supplement), 7, 40-47, 1996.

5) Labrie, F., Dupont, A., Suburu, R., Cusan, L., Tremblay, M., Gomez, J.L. and Emond, J. : Serum prostate specific antigen as pre-screening test for prostate cancer. J. Urol., 147, 846-852, 1992.

6) Catalona, W.J., Richie, J.P., Ahmann, F.R., Hudson, M.A., Scardino, P.T., Flanigan, R.C., Dekernion, J.P., Ratliff, T.L., Kavoussi, L.R., Dalkin, B.L., Waters, W.B., MacFarlane, M.T. and Southwick, P.C. : Comparison of digital rectal examination and serum prostate specific antigen in the early detection of prostate cancer : results of a multicenter 
clinical trial of 6630 men. J. Urol., 151, 1283-1290, 1994.

7) Cooner, W.H., Mosley, B.R, Rutherford, C.L, Jr., Beard, J.H., Pond, H.S., Terry, W.J., Igel, T.C. and Kidd, D.D. : Prostate cancer detection in a clinical urological practice by ultrasonography, digital rectal examination and prostate specific antigen. J. Urol., 143, 1146-1154, 1990.

8) Crawford, E.D., Schutz, M.J. and Clejan, S. : The effect of digital rectal examination on prostate specific antigen levels. JAMA., 267, 2227-2228, 1992.

9) 工藤 潔, 永田美保, 林 信義, 今村博彦, 岩本和 矢, 木村光隆, 松原正典, 三村晴夫, 松山恭輔, 諏 訪純二, 青柳直大, 宍戸 悟, 千野武裕, 千野一郎： 前立腺癌の臨床的検討. 泌尿紀要, 35, 1339-1345, 1989.

10) Imai, K. Ichinose, Y., Kubota, Y., Yamanaka, H. and Sato J. : Diagnostic significance of prostate specific antigen and the development of a mass screening system for prostate cancer. J. Urol., 154, 1085-1089, 1995.

11）梅原次男, 熊本悦明, 三熊直人, 山口康宏, 塚本泰 司, 三浦 武, 渡邊 決, 大江 宏: 北海道後志地 区における前立腺検診結果一前立腺肥大症, 前立 腺癌の頻度および症状の検討一. 泌尿紀要, 36, 415-423, 1990.
12）中川修一, 渡邊 泱, 渡辺 真, 野本剛史, 中村晃 和, 杉本浩造, 斉藤雅人, 小島宗門, 北村浩二：前 立腺特異抗原 (PSA) 濾紙法による前立腺がん検診 の試行. 日泌尿会誌, 88, 399-405, 1997.

13）清水信明, 山中英奏,一八瀬義雄, 斉藤佳隆：東暮 病院における Prostate specific antigen（PSA）単 独前立腺癌検診の試行一経過観察脱落者の検 討一. 泌尿紀要, 44, 155-158, 1998.

14）西松寛明, 河村 毅, 本間之夫, 北村唯一, 河邊香 月：前立腺癌スクリーニングにおける PSA. 泌尿 器外科, 11, 931-937, 1998.

15) Oesterling, J.E., Jacobsen, S.J., Klee, G.G., Pettersson, K., Piironen, T., Abrahamsson, P-A., Stenman, U-H., Dowell, B., Lovgren, T. and Lilja, H. : Free, complexed and total serum prostate specific antigen : The establishment of appropriate reference rangen for their concentrations and ratios. J. Urol., 154, 1090, 1995.

16) Catalona, W.J., Smith, D.S., Wolfert, R.L., Wang, T.J., Rittenhouse, H.G., Ratliff, T.L. and Nadler, R. B. : Evaluation of percentage of free serum prostate-specific antigen to improve specificity of prostate cancer screening. JAMA., 274, 1214, 1995.

(2000 年 1 月 17 日受付, 11 月 17 日受理) 